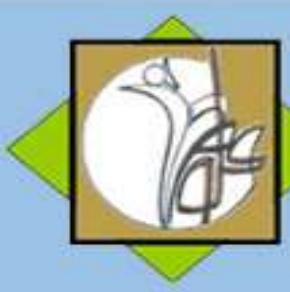

\author{
Research Article
}

\title{
Identification of Internal and External Factors Affecting the Development of Sporting Goods Export
}

\author{
Abdolhossein Ebrahimi ${ }^{1}$, Amin Khatibi ${ }^{2}$, Abdulrahman Mehdi Pour ${ }^{3}$, Hossein Marashian ${ }^{4}$ \\ 1. Abdolhossein Ebrahimi, (Ph. D student) Chamran Ahvaz University, Ahvaz, Iran. \\ 2. Amin Khatibi, (Ph. D) Chamran Ahvaz University, Ahvaz, Iran. \\ 3. Abdulrahman Mehdi Pour, (Ph. D) Chamran Ahvaz University, Ahvaz, Iran. \\ 4, Hossein Marashian, (Ph. D) Chamran Ahvaz University, Ahvaz, Iran.
}

\section{ARTICLE INFO}

Received January 2019

Accepted February 2020

\section{KEYWORDS:}

Trade, Export Development, Sport Goods,

Economic Growth

CITE:

Ebrahimi, Khatibi, Mehdi Pour, Marashian. Identification of Internal and External Factors Affecting the Development of Sporting Goods Export, Research in Sport Management \& Motor Behavior, 2021: 11(21): 124-142

\section{d.}

$\underline{10.52547 / J R S M .11 .21 .124 ~}$

\section{ABSTRACT}

This research is done with the aim of recognizing internal and external factors which are influential on exporting sportive commodities and the expansion of this export activity. From methodological point of view, this research is practical and descriptivemeasureable. In qualitative method, profound interviews and in quantitative method a quantitative-reading based questionnaire is used. Statistical society of this research include the elites of sport economy. To choose a sample volume in qualitative interviews, we used the method of theoretical sampling. Due to uncertainty of the society's volume, 384 people are picked up purposefully and by random. Analyzing the results is done by P.L.S software using structural equations. The results demonstrate that internal and external factors are influential on exporting sportive commodities with 0.526 and 0.407 impression ratios respectively. These results confirm that this structural model is adequate. On the whole and considering the findings of the research, internal influential factors on expanding the export of sportive commodities include: recognizing and reinforcement of internal factors via financial support, theoretical and technical backing, innovation in presenting services and communications, possessing strategy and external influential factors include assembling intense substructures for exporting goods, establishing commercial and political links and strategic alliance with other countries which could be influential on the export of sportive commodities. 


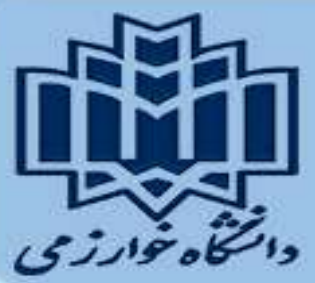

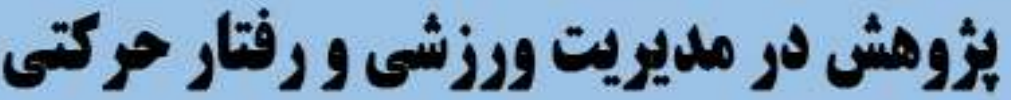

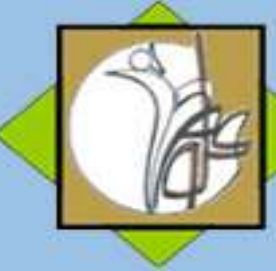

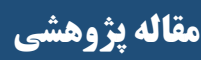

\section{شناسايى عوامل داخلى و خارجى موثر بر توسعه صادرات كالاهاى ورزشى}

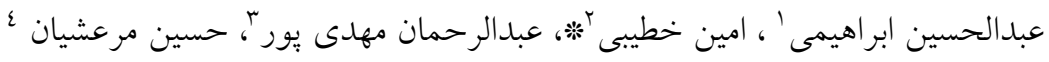

$$
\begin{aligned}
& \text { ا. دانشجوى دكترى مديريت ورزشى، دانشكده علوم ورزشى، دانشگاه شهيد جّمران اهواز ، اهواز، ايران. } \\
& \text { r. استاديار گروه مديريت ورزشى، دانشكده علوم ورزشى، دانشخاه شهيد جمران إهو اهواز ، اهواز، ايران. } \\
& \text { r. دانشيار گروه مديريت ورزشى، دانشكده علوم ورزشى، دانشخاه شهيد پِمران اهواز ، اهواز، ايران. } \\
& \text { ع. استاديار كروه مديريت ورزشى، دانشكده علوم ورزشى، دانشكاه شهيد جمر إن اهواز ، اهواز، ايران. }
\end{aligned}
$$

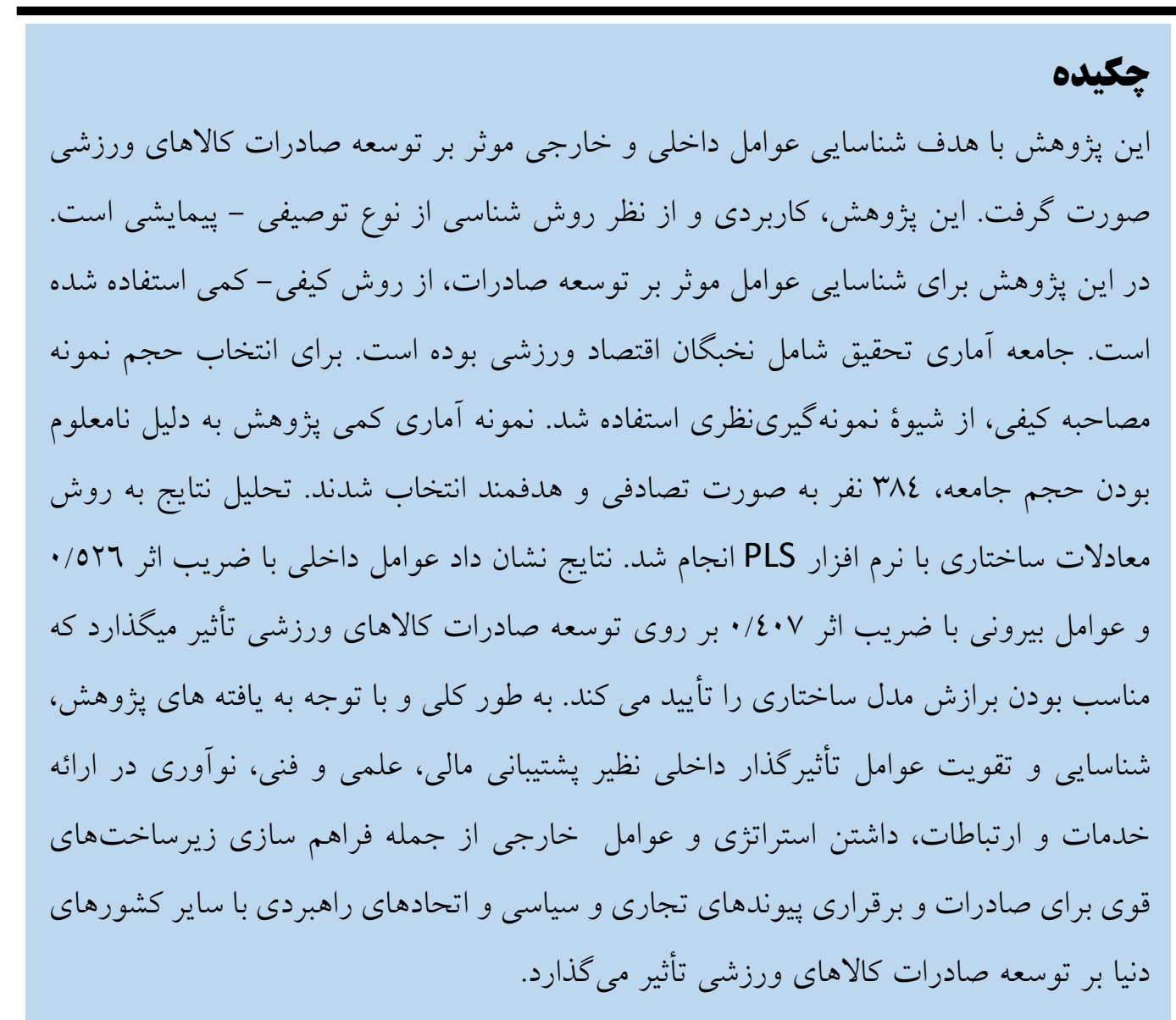

اطلاعات مقاله:

دريافت مقاله بهمن IrqV

ئذيرش مقاله بهمن

*ويسنده مسئول:

A Khatibi@scu.ac.ir

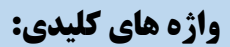

تجارت، توسعه صادرات،

كالاهاى ورزشى،

رشد اقتصادى

ارجاع:

ابراهيمى، خطيبى، مهدى يور، مرعشيان. شناسايى عوامل داخلى و خارجى موثر بر توسعه صادرات

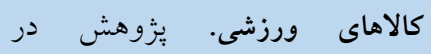

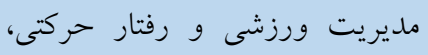
$|r \varepsilon-| \varepsilon r:(Y \mid)||: \mid \varepsilon \cdots$ 
امروزه رشد صادرات مهمترين مؤلفه بازآفرينى اقتصاد است و همانطور كه آكاهى و توجه به اهميت موضوع صادرات در كشورهاى توسعه يافته وجود دارد، تقريباً در تمام كشورهاى در حال توسعه نيز موضوع توسعه صادرات در اولويت سياست گذارىهاى دولت قرار دارد ( (1). از طرفى ديخر صادرات كالا يكى از شاخص هاى مهم توسعه يافتخى در كشورهاى بيشرفته است. ايران به عنوان يك كشور در حال توسعه نمى تواند با تكيه بر اقتصاد تك محصولى و آسيب يذير نفت در اقتصاد و تجارت جهانى نقش مهمى را ايفا نمايد، لذا براى توفيق در توسعه اقتصادى و برقرارى يك ارتباط منطقى و

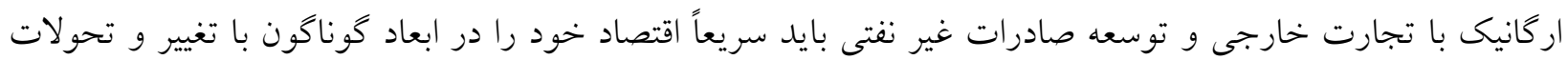
جهانى هماهنگ و منطبق نمايد (Y). در اين راستا تشديد جهانى سازى اقتصادها در دهه هاى اخير، موجب افزايش ضرورت حضور بنخاهها و توليدىها در عمليات صادرات شده و اين كرايش به جهانى سازى كسب و كار، ضرورت اهميت آكاهى

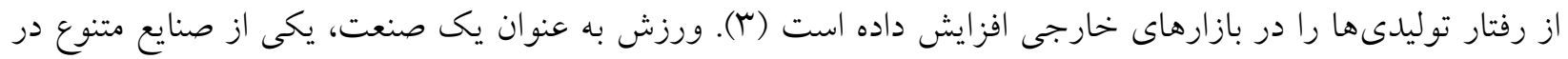
دنياى تجارت است. به لحاظ اقتصادى، يكى از عوامل مهم براى احياى اقتصاد ملى در بسيارى از كشورها است. بسيارى از كشورهاى صنعتى در حال تجربه فرهنخ جديد و رونت فعاليتهاى جسمانى هستند. با كسترش فرهنخ ورزشى جديد در اين كشورها، مصرف كالاهاى ورزشى نيز افزايش خواهد يافت كه به نوبه خود باعث استفاده جند گانه از كالاها و تجهيزات ورزشى خواهد شد (ع). گروههاى بين المللى زيادى در تجارت و توليد كالاهاى ورزشى هستند كه نقش مهمى

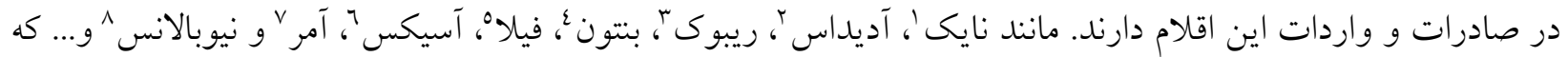
نامهاى مشهورى در اين عرصه مىباشند (0). صنعت ورزش و تجارت كالاى ورزشى از موضوعات مطرح اقتصادى مىباشد، توليد كالاهاى ورزشى اكنون يكى از حوزههاى مهم صنعتى با شاخههاى گوناگون را تشكيل مىدهد و دامنه آن هرووز گستردهتر مىشود. در بخشهاى اقتصادى جهون جهانگردى ورزشى، شركتها و مراكز ورزشى، برگزارى

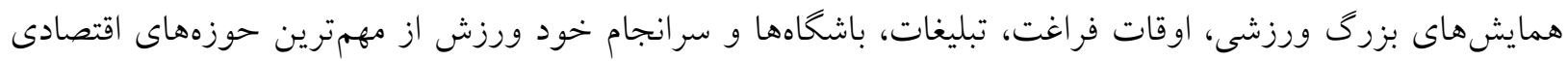
مرتبط با ورزشاند (7). مطالعات نشان مىدهد كه سهم صنعت ورزش از توليد ناخالص داخلى كشورها بين 10 • تا r

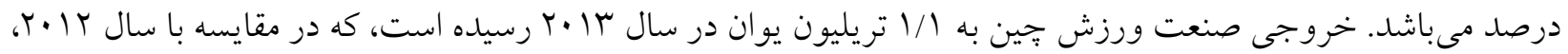

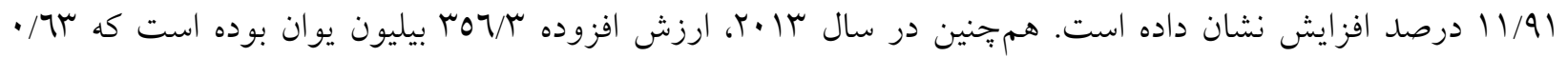
درصد توليد ناخالص داخلى را به خود اختصاص داده است، آمارها نشان مىدهد كه درآمد توليد شده در بازار جهانى

\footnotetext{
1. Nike

2 . Adidas

3 . Reebok

4 . Benetton

5 . Fila

6 . ASICS

7 . Amer

8 . New Balance
}

https://jrsm.khu.ac.ir/ 
ورزش در سال rا • rا، حدود ال ميليارد دلار آمريكا بوده است (V). در صنعت ورزش و اقتصاد ورزشى، صادرات كالاهاى ورزشى، يكى از مهمترين بخشهاى اين صنعت است كه در افزايش رشد اقتصادى كشورها نقش ويزهاى دارد. همجنين به دليل اتكاى ايران بر اقتصاد تكى محصولى و نجات از فشارها و بحرانهاى اقتصادى، لزوم توجه به اين بخش از صنعت ورزش كشور كه ظرفيت شكوفايى و توسعه آن نيز فراهم است، بيش از ييش مورد نياز است (^). در آمار سايت سازمان تجارت جهانى آمده است كه در سال 17 .r سهم كشور ما از صادرات كفش ورزشى r دهم درصد، بوشاك ورزشى 9 صدم درصد بوده است. كشور ايران در اين مدت حدود بr ميليون و •191 هزار دلار صادرات داشته كه در مقابل صادرات جهان رقم قابل توجهى نيست. كشورهاى زاين، انحليس، آلمان و امريكا بازارهاى عمده لوازم ورزشى بهشمار مىروند كه

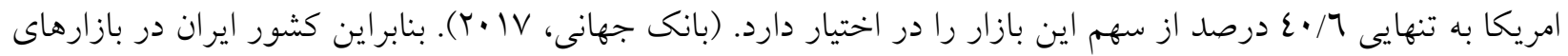
بين المللى هنوز با يارامترها و شاخصهاى مطلوب در خصوص صادرات كالاهاى ورزشى فاصله زيادى دارد. در عرصه بين الملى از آنجه مانع حضور كالاهاى ورزشى ايرانى مى گردد، تنها نمى توان فشارهاى سياسى بين المللى و سخت كيرى در راه عرضهى كالاهاى ورزشى در يارهاى از كشورها را بهانه قرار داد، بلكه عوامل داخلى نظير نبود تحقيقات بازاريابى، عدم تخصيص مناسب تعرفه صادراتى، ضعف در آمادكى فنى و تكنولوزى، نبود بستهبندى و كيفيت مناسب، بالا بودن قيمت تمام شده و ضعف در نو آورى در ارائه خدمات و ارتباطات و .... باعث شده است كه رقبا حتى در بازارهاى منطقه

$$
\text { از توليدكند گان داخلى بيشى كيرند. }
$$

از آنجايى كه صادرات كالاهاى ورزشى از جمله مهمترين پارامترها در بخش خارجى اقتصاد كشورهاى دنيا محسوب كرديده و به صورت مبنايى براى سيا ست كذارى در اين بخش مدنظر قرار دارد و به عنوان يكى از ابزارهاى سياسى در بعد خارجى اقتصاد در غالب راهبردها و برنامههاى تو سعه قرار دارد، شناخت عوامل داخلى و خارجى كه بر صادرات اثر كذار هسـتند، بسـيار مهم و ضـرورى اسـت. عوامل زيربنايى داخلى و خارجى بسـيارى در ايجاد توسـعه و تقويت صادرات بين الملل در كشورها و شركتها وجود دارند. بررسى مطالعات كذشته نشان مى دهد كه تاكنون تحقيقات كمى درباره شناسايى عوامل داخلى و خارجى موثر بر توسعه صادرات كالاهاى ورزشى انجام شده است و آنجّه در اين زمينه انجام شده است بيشتر آمار و ارقام صادرات كالاهاى ورزشى بوده است. از اين رو در راستاى موضوع يزوهش در داخل كشور نتايج تحقيق خدادادى و همكاران (IrqV) با موضوع اثر تحريم بر تجارت ايران و شركاى عمده تجارى در صنعت ورزشى نشان مىدهد كه اثر جمعيت و توليد ناخالص داخلى به ترتيب در تمام كشورها منفى و مثبت بوده، نرخ ارز به غير روسيه و قرقيزستان منفى بوده، تحريمهاى ضعيف دوره حاضر به غير قزاقزستان و قرقيزستان منفى بوده، تحريمهاى قوى دوره فعلى در تمام كشورها مثبت بوده، تحريمهاى ضعيف دوره قبل به غير از جين در بقيه كشورها منفى بوده و تحريمهاى قوى دوره قبل بر جين، قزاقزستان و قرقيزستان اثر منفى داشته است (9). در دوران يساتحريم، روند صعودى تجارت ايران با شركا در صنعت ورزش

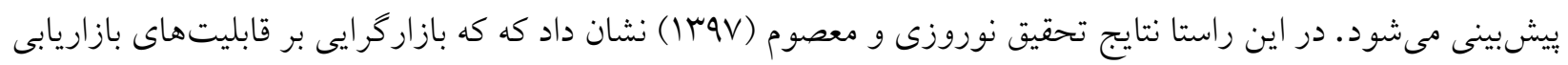

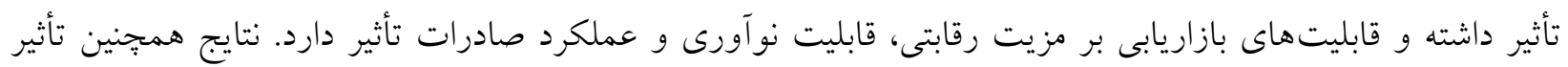


مزيت رقابتى و قابليت نو آورى بر عملكرد صادرات را تأييد نموده است (•) (1). هم:جنين نتايج تحقيق شهبازى و همكاران (I IVV) صادراتى بر عملكرد صادراتى تأثير مى گذارد (1). در راستاى موضوع ثيزوهش، رضايى (1797)، به بررسى تأثير استراتزىهاى بازاريابى بين الملل بر عملكرد صادراتى در شركتهاى توليدى و صادراتى تيرداخت. نتايج مطالعه وى نشان مىدهد كه استراتزىهاى بازاريابى بينالملل بر عملكرد صادراتى تأثير معنادارى دارد. همجنين استراتزى كاملاً

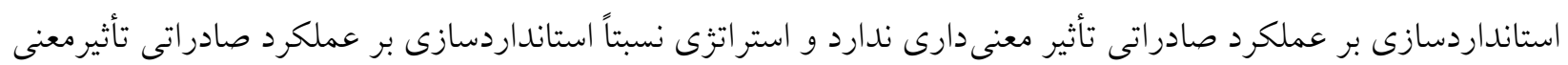
دارى ندارد، اما استراتزى كاملا انطباقى تأثير معنى دارى بر عملكرد صادراتى دارد و همجينين استراتزى نسبتاً انطباقى تأثير معنى دارى بر عملكرد صادراتى ندارد (11). همجنين تجزيه و تحليل نتايج يزوهش مفردى و شيخزاده (90ب1) نشان مىدهد كه عمدهترين موانع توسعه صادرات از ديدكاه صادركنندكان به ترتيب شامل: () نوسانات و تغييرات مداوم نرخ بهره و نرخ ارز، ץ) وجود نداشتن برنامهريزى راهبردى براى نفوذ و ورود به بازارهاى جهانى، ؟) نداشتن تفكر جهانى شدن بين مديران شركتها و عمدهترين راهكارهاى توسعه صادرات از ديدكاه صادركنندكان به ترتيب شامل: ( ) برخوردارى از امكانات حمل و نقل مناسب و مجهز زمينى و دريايى و غيره جهت صدور كالا، Y) برخوردارى از مهارت و دانش فنى در زمينه توليد محصولات مرغوب و با كيفيت جهت صادرات، r) برخوردارى از زيرساختهاى بيشرفته نظام بانكى و نظام ارتباطات در داخل كشور جهت صادرات مىباشند (Y). نتايج يزوهش شوقى و همكاران (ع Ir) نشان داد به ترتيب اولويت تبليغات، منابع مالى، مواد اوليه، يزوهش هاى بازاريابى، تكنولوزى و دانش فنى، زيرساختهاى مورد نياز، كيفيت محصولات، شدت رقابت بين المللى، نخرش راهبردى، حمايت و نقش دولت، وجود صنايع مرتبط بعنوان عوامل موثر بر صادرات كالاهاى ورزشى شناخته شدهاند (r). در راستاى موضوع يزوهش، تحقيقات متنوعى در خارج كشور انجام شده است. نتايج تحقيق كراكا و همكاران (Y.IV) نشان داد كه نو آورى فناورانه در توسعه اقتصادى و افزايش صادرات نقش مهمى دارد. ميزان صادرات فناورىهاى بيشرفته نيز يكى از شاخصهاى مهم توسعه اقتصادى كشورها است. از اين رو سطح محصولات ورزشى با فناورى بالا عامل تعيين كننده سطح توسعه اقتصادى و اجتماعى يك كشور و نوع نقش آن كشور در اقتصاد جهانى است (r) (I). همجنين غلامزاده (17 (Y) در تحقيق خود با عنوان ورزش به عنوان يك صنعت در فنلاند به بررسى علايم اقتصادى، كمى و توسعهى بخش ورزش به عنوان يك صنعت يرداخت. نتايج نشان مىدهد كه متوسط توليد ناخالص داخلى بخش ورزشى در فنلاند بيش از دو ميليارد و يكصد و هشتاد ميليون يورو است كه به طور متوسط به درصد آن توسط خدمات و V درصد توسط توليد كالا مىباشد، توليد ناخالص داخلى در بخش ورزشى در تجزيه و تحليل كلى به طور متوسط در ب/9 درصد در سطح

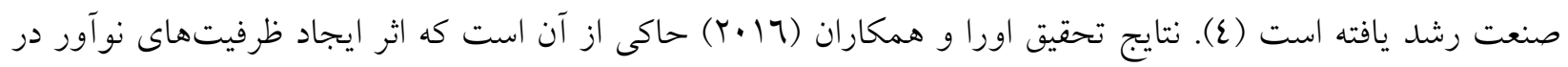

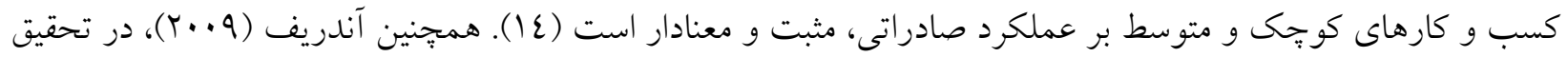
خود با عنوان، تجارت جهانى كالاهاى ورزشى، تخصص گرايى بين المللى كشورهاى عمدهى تجارى را مورد بررسى قرار داد. مجموعهى دادهاى اع كشور، 7س محصولات مختلف ورزشى و 97-9 درصد از تجارت كالاهاى ورزشى جهانى 


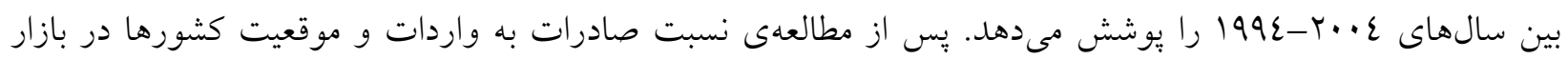
جهانى مناطق تجارى مهم كالاهاى ورزشى آسيا، ارويا و كشورهاى نفتا (ايالات متحده آمريكا، مكزيك و كانادا) معرفى بـ بـ شدند. همجنين، صادر كنند كان عمده كالاهاى ورزشى عبارتند از: جِين، هنگ كنگ، ايالات متحده آمريكا و فرانسه و

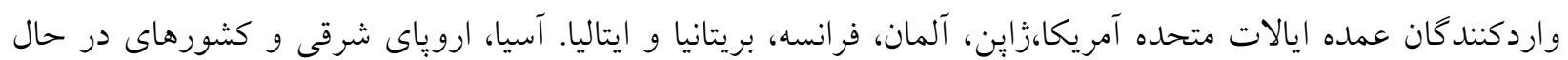

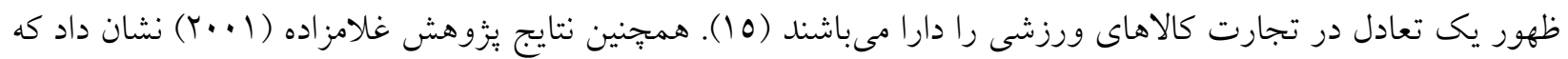
تجارت كالاهاى ورزشى ميزان كسب و كار را افزايش دادهو بيش از r/ • درصد از كل تجارت جهانى را به خود اختصاص داده است. همجنين نتايج حاكى از اين است كه مهمترين صادر كننده و واردكنندهى كالاهاى ورزشى، كشورهاى صنعتى و توسعه يافته مىباشند (17 ). امروزه بيشتر كشورهاى توسعه يافته از تمام يتانسيلهاى خود براى توسعه صادرات كالاهاى ورزشى استفاده مى كنند، اما بررسىها نشان مىدهد كه كشورايران با وجود برخوردارى از ظرفيتهاى بالاى صادراتى كالاهاى ورزشى، سهم كمى از بازارهاى بين المللى را در اختيار دارد و با وجود روند صعودى آن از زمان برنامه سوم تو سعه، همجنان فاصله زيادى با

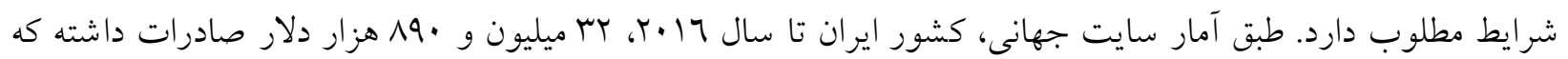
در مقابل صادرات جهان رقم قابل توجهى نيست. بنابراين سهم ايران بسيار كمتر از استاندارد جهانى آن مىباشد. بررسى مبانى نظرى و ادبيات تحقيق در زمينه توسعه صادرات كالاهاى ورزشى نشان مىدهد كه عوامل داخلى و خارجى زيادى مى تواند بر توسعه صادرات كالاهاى ورزشى تأثير بحذارد. از اين رو محقق با توجه به مبانى نظرى تحقيق از مدل عوامل

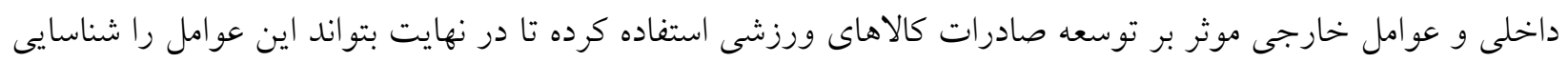

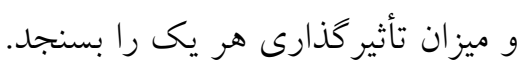

\section{روش شناسى تحقيق}

هدف يزوهش حاضر شناسايى عوامل داخلى و خارجى موثر بر توسعه صادرات كالاهاى ورزشى مىباشد. اين يزوهش يك يزوهش كاربردى و از نظر روش شناسى از نوع توصيفى - ييمايشى است. در اين تحقيق از روش كيفى - كمى استفاده شده است. در روش كيفى از روش مصاحبه عمقى و در روش كمى از ابزار يرسشنامه مبتنى بر مطالعه كيفى استفاده

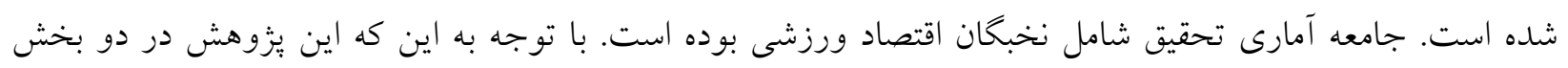
جداكانه انجام شد، در بخش اول كه مطالعه كيفى است، به منظور طراحى مدل مفهومى تحقيق، جامعه آمارى يزوهش،

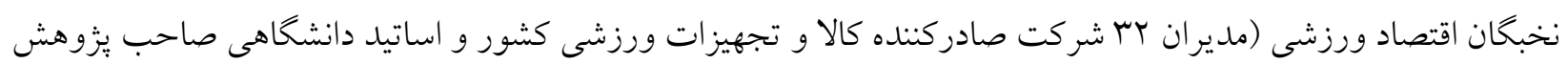
در حوزه بازاريابى و اقتصاد ورزشى) هستند. در بخش دوم كه به آزمون آمارى مدل تحقيق برداخته مى شوده، جامعه نيز نخبشان اقتصاد ورزشى هستند. براى انتخاب حجم نمونه مصاحبه كيفى، از شيوه نمونه كيرىنظرى استفاده شد. براى

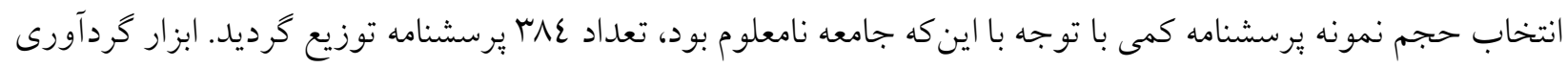
دادهها يرسشنامه بود. بِ از مصاحبه دقيق با نخبخان اقتصاد ورزشى و به كاركيرى روش تحليل محتواى كيفى عوامل داخلى و خارجى مؤثر بر توسعه صادرات كالاهاى ورزشى و شاخصهاى مربوط به هركدام از آنها استخراج شد. براى 
برآورد روايى ثيرسشنامه از روش روايى صورى استفاده شده است. به اين ترتيب، در اين يزوهش به منظور اطمينان از دقت وسيله اندازه گيرى، يُ از آن كه شاخصها و عوامل اوليه موثر بر توسعه صادرات با مصاحبه و مرور بيشينه تحقيق مشخص شد، برسشنامه اوليه تدوين شده است. در ادامه، يرسشنامه مذكور به رويت اساتيد راهنما، مشاور و تنى جنا از خبر گان صادرات رسيد تا وسيله اندازه گيرى را از نظر محتوايى اعتبار سنجى كرده و بيشنهادهايشان را ارائه دهند. اين

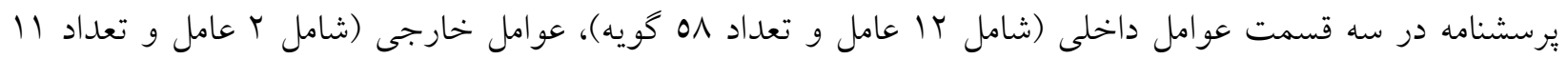
كويه) و مؤلفههاى مربوط به توسعه صادرات (شامل يك عامل و تعداد 7 گويه) تنظيم گرديد. در نهايت مقدار بايايى تركيبى، روايى واكرا و همخرا يرسشنامه مطلوب برآورد شد. در ادامه يرسشنامه نهايى را بين ع^ب نفر توزيع شد كه تعداد

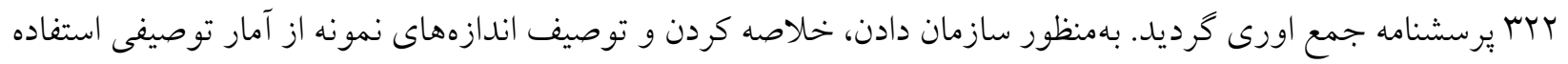
شد. تحليل نتايج اين مطالعه به روش معادلات ساختارى با نرم افزار بي ال اس هنسخه دو انجام شده است.

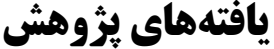

برخى اطلاعات جمعيتشناختى افراد نمونه از قبيل جنسيت، سن، تأهل، تحصيلات و وضعيت اشتغال در جدول شماره يك آمده است.

جدول اـ توصيف برخى ويزگى هاى جمعيت شناختى افراد نمونه

\begin{tabular}{|c|c|c|c|}
\hline درصد فراوانى & فراوانى & ويزگى هاى جمعيتشناختى & متغير \\
\hline 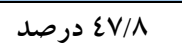 & $10 \varepsilon$ & زن - ت ان & \multirow[t]{2}{*}{ جنسيت } \\
\hline & 171 & 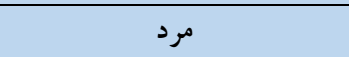 & \\
\hline r & $1 \varepsilon 9$ & $r \cdot$ ro & \multirow[t]{5}{*}{ سن } \\
\hline & $1 \cdot 1$ & m_E. & \\
\hline |r/ع ا درصد & $\varepsilon r$ & $\varepsilon 1 \_\varepsilon 0$ & \\
\hline ك/ & $1 \varepsilon$ & ¿า_o. & \\
\hline T/O درصد & $\wedge$ & إه به بالا & \\
\hline آ & irr & 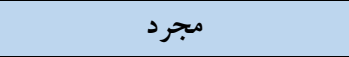 & \multirow[t]{2}{*}{ تأهل } \\
\hline ON/V درصد & 119 & متأهل & \\
\hline 1/9 درصد & 7 & دييلم و فوقدييلم & \multirow{4}{*}{ تحصيلات } \\
\hline 1/7/7 درصد & $r \varepsilon$ & 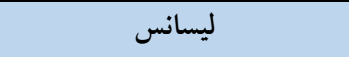 & \\
\hline 促 & 149 & فوقليسانس & \\
\hline 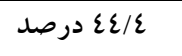 & $1 \varepsilon r$ & دكترا & \\
\hline جدرصد & rq & مدير توليدى & \multirow{4}{*}{ وضعيت } \\
\hline 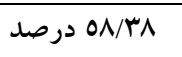 & $1 M$ & هيئت علمى و مدرس دانشخاه & \\
\hline 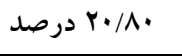 & TV & دانشجو & \\
\hline ل • II/A درصد & ru & ساير & \\
\hline
\end{tabular}

9. PLS

https://jrsm.khu.ac.ir/ 
ماهيت اين يزوهش، اكتشافى - بنيادى و رويكرد آن كيفى است كه از راهبرد دادهبنياد استفاده شده است. هدف يزوهش، دسـتيابى به مدل يارادايمى براسـاس دادههايى اسـت كه با اسـتفاده از مصــاحبههاى نظاممند و مطالعات نظرى موجود كردآورى شدهاند. برر سى عوامل مؤثر بر تو سعه صادرات كالاهاى ورزشى با استفاده از راهبردهايى است كه طى جند مرحله كد كذارى به يِيامدهايى منجر مىشــوند و اين بيامدها همان نتايجى هسـتند كه بررسـى عوامل موثر بر توسـعه صادرات كالاهاى ورز شى به آن منجر مى شوند. در اين يزوهش، از طرح نظاممند راهبرد ا ستراوس و كوربين (11) اسـتفاده شــه اسـت. مرحله اول با اسـتفاده از مطالعهُ كتابخانهاى و مرور نظاممند يزّوهشهاى كذشـته در اين زمينه، به سؤالهاى نيمه باز و نيمه بستهاى براى انجام مصاحبه با بr نفر از متخصصان اين حوزه ( مديران شركتهاى صادركننده كالا و تجهيزات ورز شى كشور و ا ساتيد دانشخاهى صاحب يزوهش در حوزه بازاريابى و اقتصاد ورزشى) منتج شده ا ست. بر ا ساس طرح نظاممند نظرئدادهبنياد، براى تحليل دادهاى كيفى گردآورى شده بايد سه مرحله كدگذارى باز، محورى و انتخابى انجام شود تا در نهايت، يارادايمى منطقى يا تصويرى عينى از نظرية خلق شده ارائه شود. عوامل نهفته در اين آزمون با روش تحليل مؤلفهاى اصلى و جرخش واريماكس استخراج شد. در اين مدل عامل نهفته در آزمون با توجه به ارزشهاى ويزهه بالاتر از ادر جدول شماره ب و نمودار ا طرح سنگ ريزه بدست آمد. نتايج حاصل در جدول r واريانس تبيين شده كلى با ارزش ويزه بالاتر از يك را در اين آزمون ذشان داد كه ارزشهاى

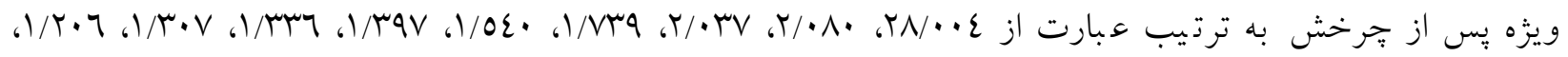

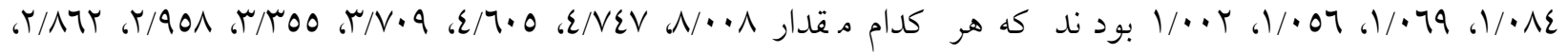
Tr/A متغيرهاى آزمون را تبيين مى كنند. 
جدول شماره Y- ارزشهاى ويزٌه بالاتر از يك براى سيزده عامل اوليه

\begin{tabular}{|c|c|c|c|c|c|c|c|c|c|}
\hline 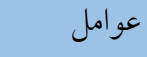 & \multicolumn{3}{|c|}{ مقادير ويزه } & \multicolumn{3}{|c|}{ ميز ان استخراج مجموع مجذورات } & \multicolumn{3}{|c|}{ ميزان جرخش مجموع مجذورات } \\
\hline & كل & 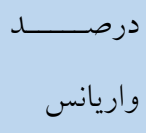 & درصـــــ & كل & 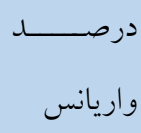 & ترجمعـى & كل & 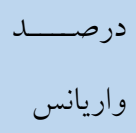 & تربمعى \\
\hline يشتيبانى & $r \wedge / \cdots \wedge$ & $\varepsilon \cdot 109 r$ & $\varepsilon \cdot 109 T$ & $r \wedge / \cdots \wedge$ & $\varepsilon \cdot 1094$ & $\varepsilon \cdot / 09 r$ & $\wedge / \cdots \wedge$ & $11 / 7 \cdot 7$ & $11 / 7 \cdot 7$ \\
\hline صحه كذارى & $r / \bullet$. & $r / \cdot 1 \varepsilon$ & $\varepsilon r / \eta \cdot\rceil$ & $r / \bullet \wedge$. & $r / \cdot 1 \varepsilon$ & $\varepsilon r / \eta \cdot \tau$ & $\varepsilon / V \varepsilon V$ & 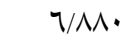 & 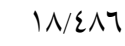 \\
\hline خدمات & $r / \cdot r V$ & r/90r & $\varepsilon 7 / 001$ & $T / \cdot r V$ & r/90r & $\varepsilon 7 / 00 \wedge$ & $\varepsilon / 7 \cdot 0$ & $\tau / 7 \vee \varepsilon$ & $r 0 / 171$ \\
\hline استراتثى & $1 / v r q$ & Y/OYI & $\varepsilon q / \cdot \vee q$ & $1 / N T^{\prime}$ & T/OYI & $\varepsilon q / \cdot v q$ & $r / v \cdot q$ & $O /$ TVO & $r \cdot / 0 r 7$ \\
\hline نهادها & $1 / 0 \varepsilon$. & T/YMT & $01 / \pi 11$ & $1 / 0 \varepsilon$. & T/TMT & $01 / \pi 11$ & r/roo & $\varepsilon / \wedge T Y$ & ro/rqA \\
\hline فضا & I/rqV & $r / \cdot T_{O}$ & רسז/אם & $1 / \mu q V$ & $r / \cdot T_{O}$ & רسז/אם & $r / 901$ & $\varepsilon / T \wedge V$ & $r q / u 0$ \\
\hline فنى & דאזו1 & $1 / 947$ & $00 / Y V I$ & דוזאו & $1 / 947$ & $00 / Y V 1$ & $r / \Lambda T r$ & $\varepsilon / 1 \varepsilon V$ & $\sum r / \Lambda T Y$ \\
\hline شرايط بازار & $1 / \mu \cdot V$ & $1 / \wedge 9 \varepsilon$ & $0 V / 170$ & $1 / \mu \cdot v$ & $1 / 19 \varepsilon$ & $0 V / 170$ & T/AYT & $2 / .90$ & $\varepsilon V / Q T V$ \\
\hline سرمايه انسانى & $1 / T \cdot 7$ & I/VEV & $0 N / 91 Y$ & $1 / T \cdot 7$ & I/V $\varepsilon V$ & $0 N / 91 Y$ & T/NIT & $\varepsilon / \cdot V V$ & or $/ \cdots \varepsilon$ \\
\hline حمايت ها & $1 / \wedge \varepsilon$ & I/OVT & $7 \cdot / \varepsilon \wedge \varepsilon$ & $1 / \cdot \wedge \varepsilon$ & I/OVT & $\eta \cdot / \varepsilon \wedge \varepsilon$ & $T / \Sigma T r$ & $r / 01$. & $00 / 010$ \\
\hline اقتصادى & $1 / 79$ & $1 / 0<9$ & س & $1 / .79$ & $1 / 0 \varepsilon 9$ & Tr/M & $r / \varepsilon \mid \wedge$ & $r / 0.0$ & $09 / \cdot 19$ \\
\hline نوآورى & $1 / .07$ & 1/or. & r/07/ & $1 / .07$ & l/or. & אד/4/0 & $T / T \cdot r$ & r/l9r & $\pi / T / Y$ \\
\hline سارجي ست تجارت & $1 / \cdots r$ & l/EOr & $70 / \cdot 10$ & $1 / \cdots r$ & l/EOr & $70 / \cdot 10$ & س 1/94 & $r / \Lambda \cdot r$ & $70 / \cdot 10$ \\
\hline
\end{tabular}

شيب دامنه متغيرها در اين آزمون در نمودار يك نشان داده شده است.

Scree Plot

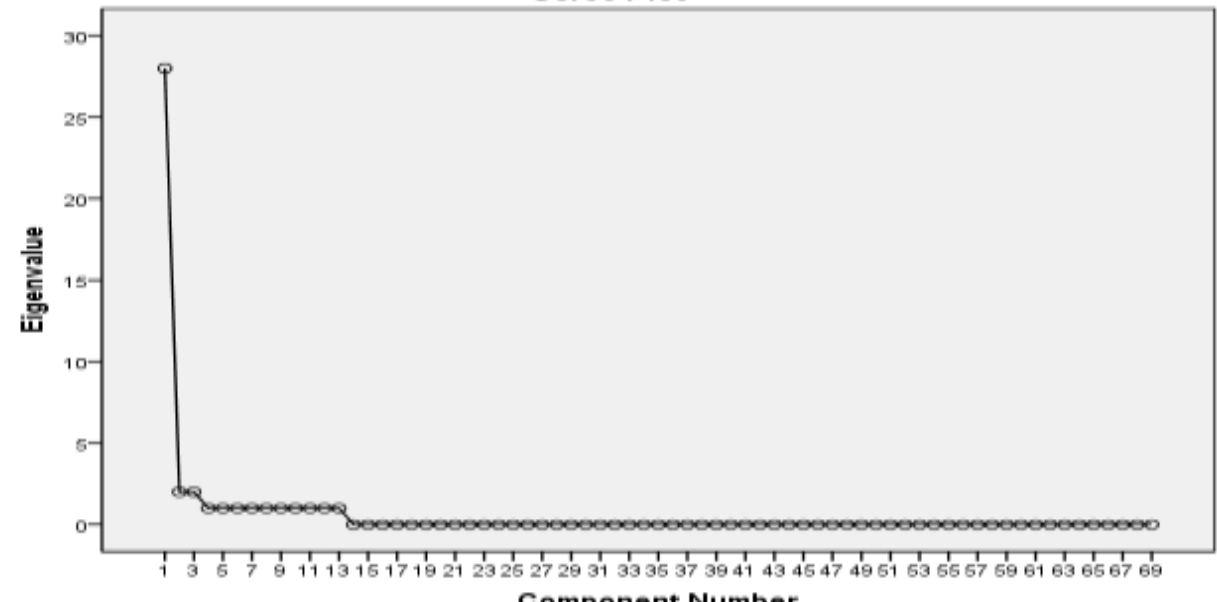

Component Number

نمودار شماره ا- نمودار شيب دامنه متغيرهاى آزمون 


\section{بررسى نرمال بودن دادهها}

براى تعيين طبيعى بودن توزيع دادهها از آزمون كولموكروف اسميرونوف استفاده شد. براساس اين آزمون، توزيع وقتى

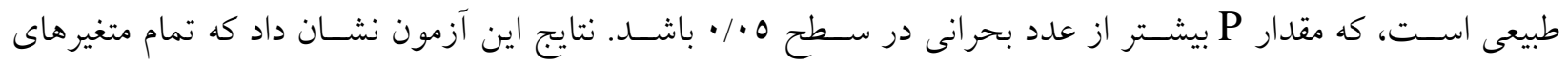
اندازهكيرى داراى توزيع غير طبيعى مىباشند. نتايج اين آزمون در جدول دو ارائه شده است.

جدولr- آزمون كلمو گراف- اسميرنوف براى تعيين توزيع نرمال داده هاى برّوهش

\begin{tabular}{|c|c|c|}
\hline سطح معنادارى & مقدار z & مولفه ها \\
\hline$\cdot / \cdots 1$ & $r / 01 r$ & يشتيبانى مالى، علمى و فنى \\
\hline.$\cdots 1$ & $4 / 14$ & صحه گذارى ورزشكاران و متخصصين مشهور \\
\hline$\cdot 1 \cdot \cdot 1$ & $1 / 9 \mathrm{VI}$ & نوآورى در ارايه خدمات و ارتباطات \\
\hline$\cdot / \cdots 1$ & $1 / 197$ & تو انمندى بنگاهها در خصوص استراتزى و ساختار \\
\hline.$\cdots 1$ & $T / \varepsilon \varepsilon 1$ & نهادهاى بخش خصوصى و تعاونى \\
\hline$\cdot \cdots 1$ & $r /\{\wedge 9$ & اندازه فضا و محيط بازار \\
\hline$\cdot / \cdots 1$ & $r / l$ & آمادكى فنى و تكنولوزى \\
\hline$\cdot / \cdots 1$ & T/V7. & شرايط بازار \\
\hline$\cdot / \cdots 1$ & $r / \mu \cdot \Lambda$ & سرمايه انسانى \\
\hline$\cdot / \cdots 1$ & $r / 01 \%$ & حمايتها و مشوقهاى نهادهاى دولتى \\
\hline$\cdot / \cdots 1$ & r/A70 & شرايط اقتصادى \\
\hline$\cdot / \cdots 1$ & $1 / 9 V Y$ & نو آورى در محصول \\
\hline$\cdot / \cdot v$ & $1 / 7 \wedge \vee$ & يبيوندهاى تجارت و توانمندى در اقتصاد بين المللى \\
\hline$\cdot / \cdots 1$ & 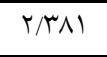 & سياستهاى تجارت خارجى \\
\hline$\cdot / \cdot 1$ & INQT & توسعه صادرات \\
\hline
\end{tabular}

با توجه به اينكه دادههاى جمع آورى شده غير نرمال بوده است و استفاده از نرمافزارهاى كوواريانس (ليزرل و ايموس) محور منوط به نرمال بودن دادهها مىباشد، بنابراين از نرم افزار بيى ال اس نسخه دو استفاده مى شود، جون يكى از مزاياى اصلى اين نرم افزار تحليل دادههاى غير نرمال مىباشد (IV). 


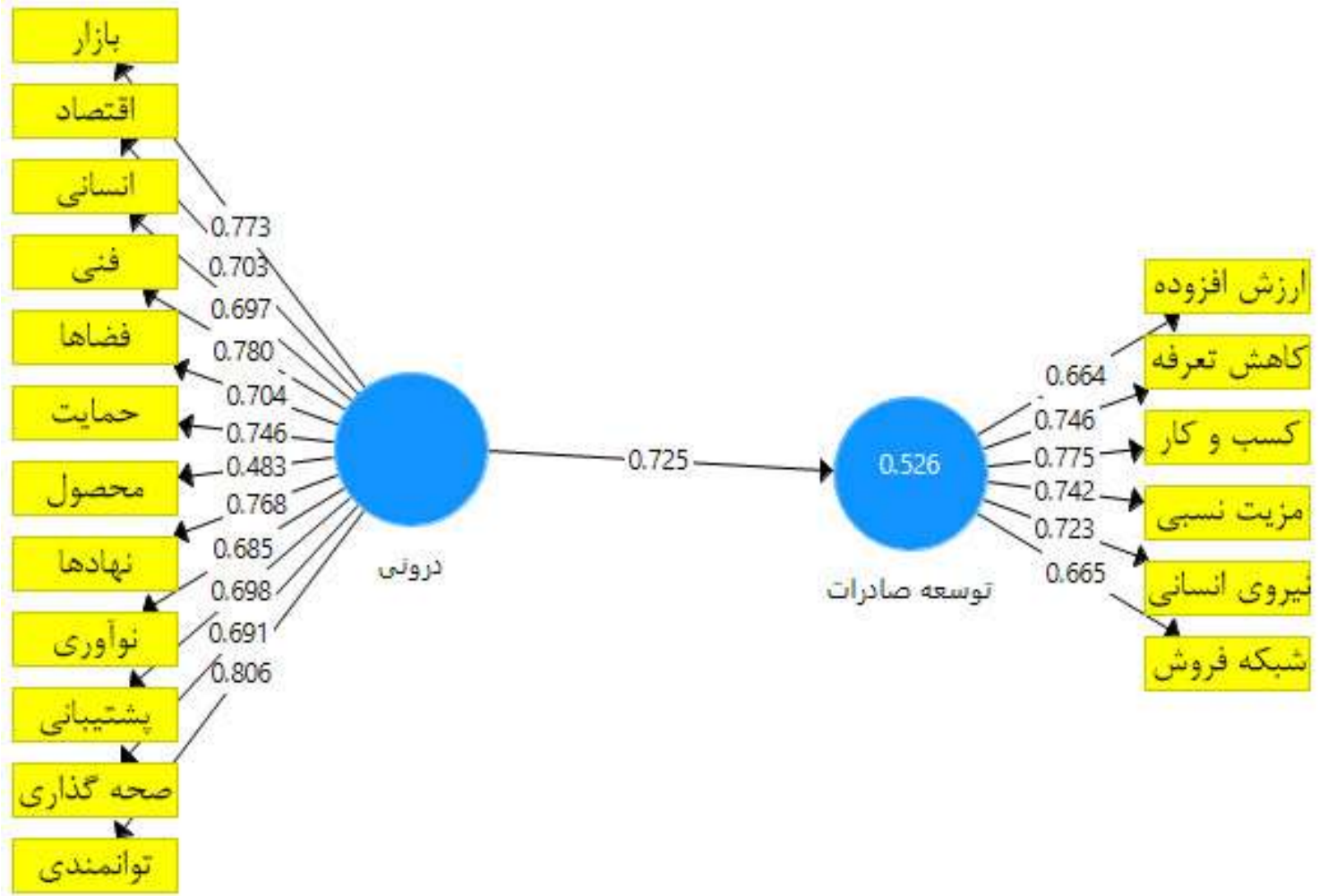

شكل ا-تاثيرعوامل داخلى بر توسعه صادرات كالاهاى ورزشى در حالت استاندارد

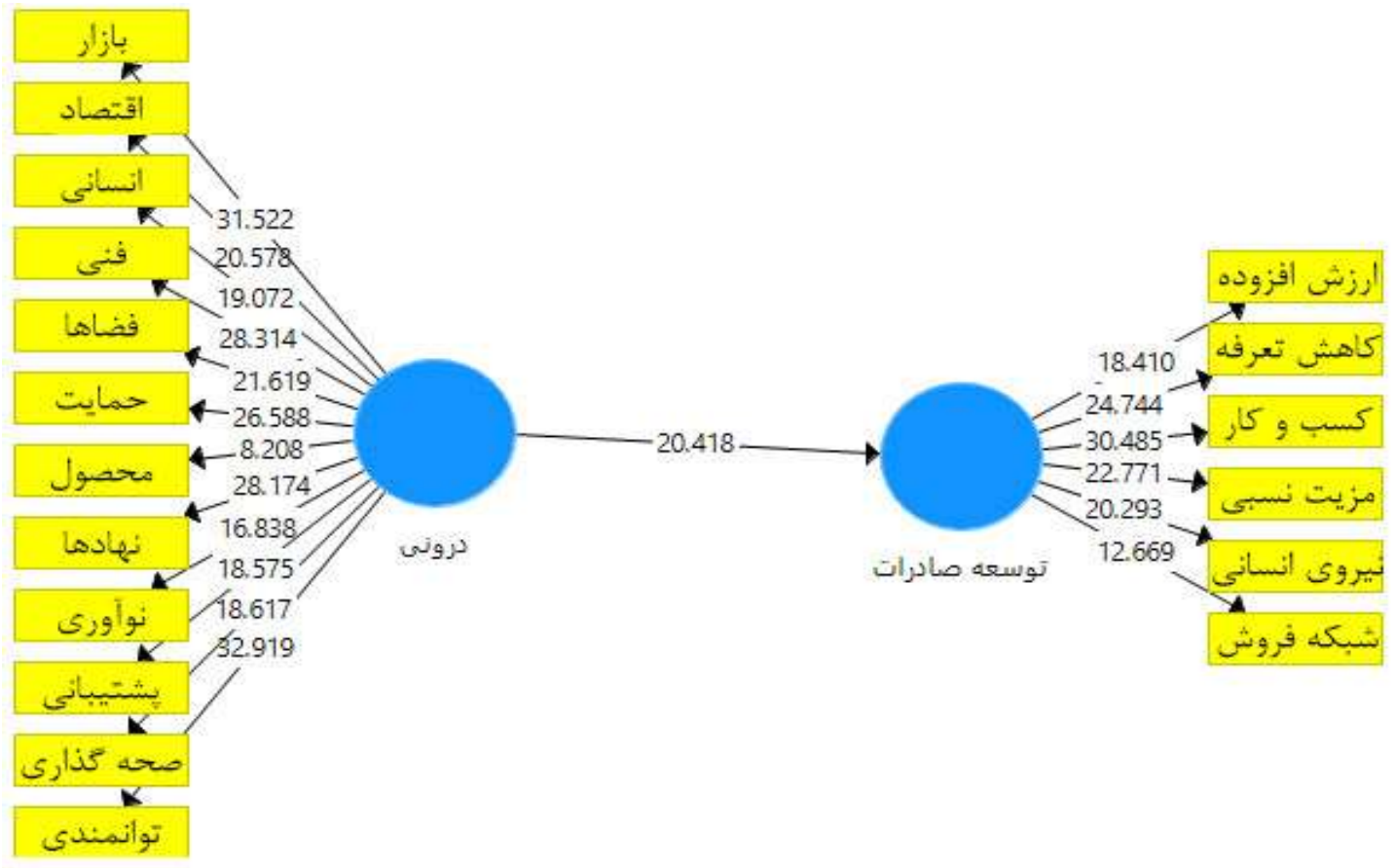

شكل ب-تاثيرعوامل داخلى بر توسعه صادرات كالاهاى ورزشى در حالت معنادارى

https://jrsm.khu.ac.ir/ 
مطابق با شكل ا مقدار R2 براى سازه توسعه صادرات ورزشى 1 م / • محاسبه شده است كه با توجه به سه مقدار ملاكى

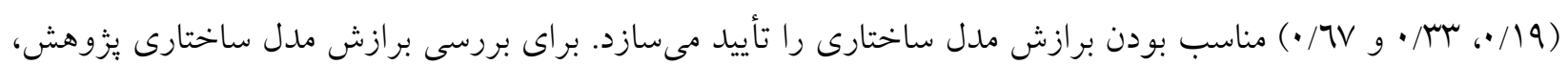

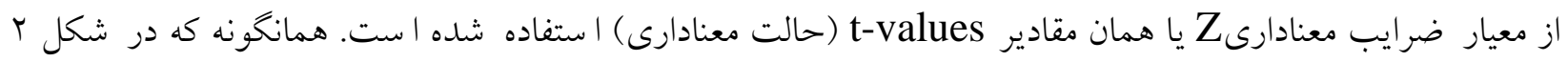

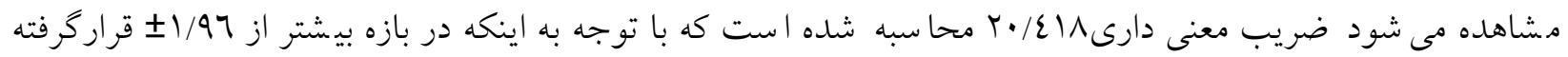

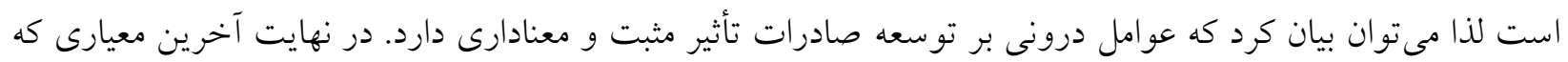
لازم است بررسى كردد، معيار قدرت بيشبينى مدل Q2 است. از آنجاى كه مقدار سازه درونزاى تو سعه صادرات ورزشى به / • برآورد شده است، اين نشان از قدرت بيشبينى مدل در خصوص اين سازه را دارد و برازش مناسب مدل

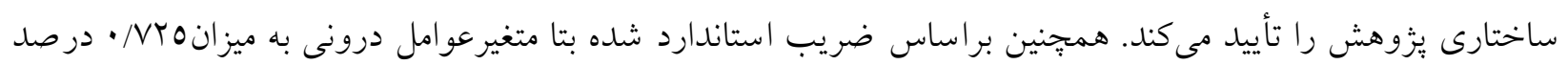
از تغييرات متغير توسعه صادرات ورزشى را تبيين مى كند.

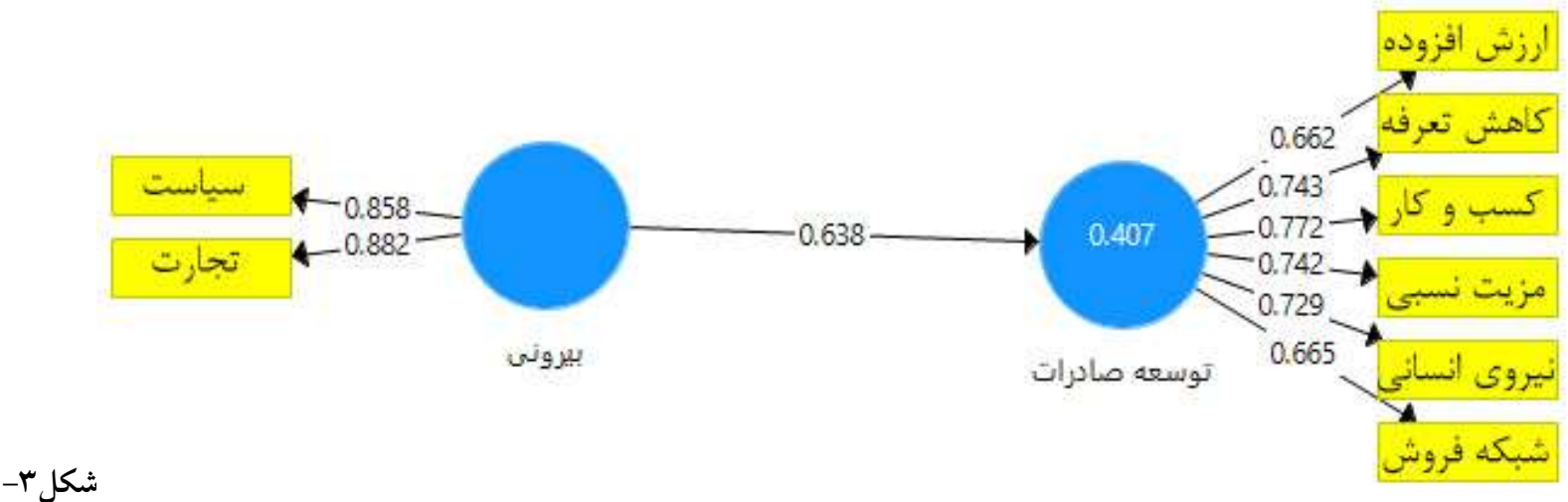

تاثيرعوامل خارجى بر توسعه صادرات كالاهاى ورزشى در حالت استاندارد

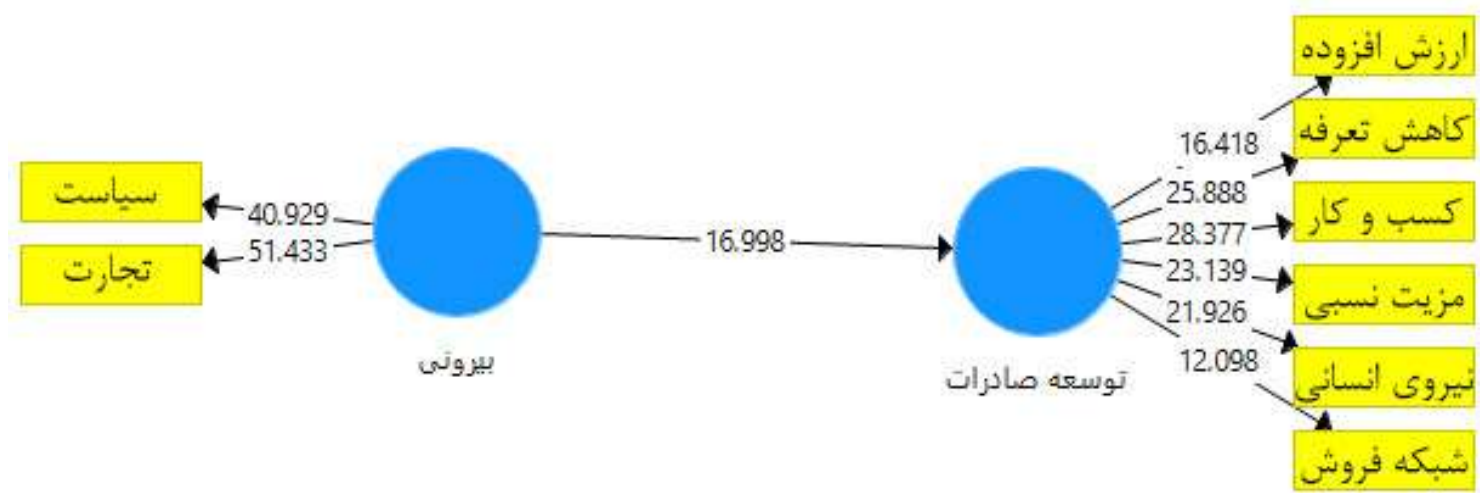

شكل ع-تاثيرعوامل خارجى بر توسعه صادرات كالاهاى ورزشى در حالت معنادارى 
مطابق با شكل سه مقدار R2 براى سازه تو سعه صادرات ورز شى V•ع/• محاسبه شده است كه با توجه به سه مقدار ملاكى (9/ •، سٓ/• و VV/•) منا سب بودن برازش مدل ساختارى را تأييد مى سازد. براى برر سى برازش مدل ساختارى

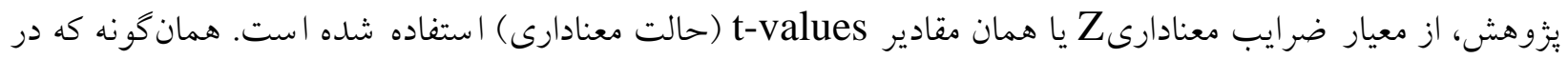
شكل عمشاهده مى شود ضريب معنى دارى 17/991 محاسبه شده است كه با توجه به اينكه در بازه بيشتر از 1/97 قرارگرفته است لذا مىتوان بيان كرد كه عوامل بيرونى بر تو سعه صادرات تاثير مثبت و معنادارى دارد. در نهايت آخرين

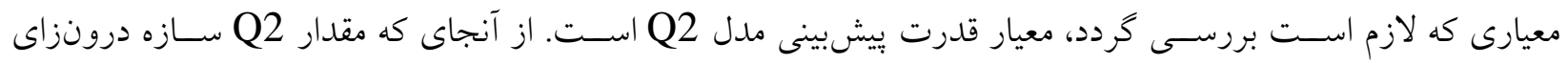
تو سعه صادرات ورزشى 190/ • برآورد شده است، اين ذشان از قدرت يُشبينى مدل در خصوص اين سازه را دارد و

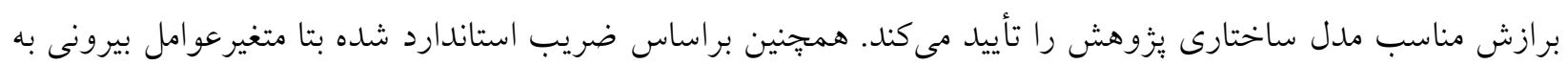
ميزان^شا/ • درصد از تغييرات متغيرتوسعه صادرات ورزشى را تبيين مى كند.

براى هر مسـيرى مىتوان اندازه اثر را با اسـتفاده از F2 كوهن ارزيابى كرد. طبق نظر كوهن مقادير r٪/ ، براى F2 به ترتيب بيان كر اندازه اثر كوجك، متوسط و بزرى است. مقدار f2 كوهن از رابطه زير محاسبه كرديده است. $\mathrm{F} 2=(\mathrm{R} 2$ Included $-\mathrm{R} 2$ Excluded $) /(1-\mathrm{R} 2$ Included $)$

همانطور كه در جدول سه مشاهده مى شود مسير عوامل درونى به تو سعه صادارات ورزشى داراى اثر كوخجى و مسير عوامل بيرونى به توسعه صادارات ورزشى داراى اثر متوسط مىباشد.

جدول سه- مقدار اندازه اثر

\begin{tabular}{|c|c|c|c|c|}
\hline اندازه اثر & F2 & $\begin{array}{c}\mathbf{R 2} \\
\text { Excluded }\end{array}$ & $\begin{array}{c}\text { R2 } \\
\text { Included }\end{array}$ & مسير \\
\hline كوجى &.$/ 111$ & $\cdot / \Sigma q 4$ &.$/ 0 \varepsilon \varepsilon$ & مسير عوامل درونى به توسعه صادرات \\
\hline متوسط & $\cdot / T Y \Lambda$ & $\cdot / \varepsilon \cdot 9$ & $\cdot / 0 \varepsilon \varepsilon$ & مسير عوامل بيرونى به توسعه صادرات \\
\hline
\end{tabular}

بحث و نتيجه كيرى

امروزه برقرارى روابط تجارى و استفاده از فرصتها در بازارهاى خارجى از مقاصد مهم دولتها به شمار مى آيد كه منجر به كسب درآمد ارزى و شكوفايى هر تهه بيشتر اقتصاد آن كشور خواهد شد. هدف اصلى اين يزوهش شناسايى عوامل داخلى و خارجى موثر بر توسعه صادرات كالاهاى ورزشى بوده است كه انتظار مىرود نتايج اين يزّوهش بتواند مديران

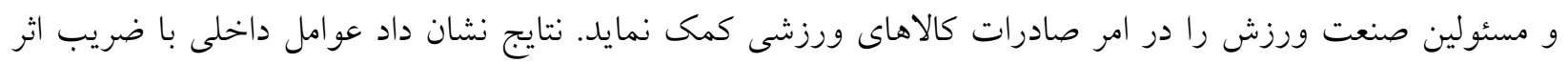
7ror/ • و عوامل بيرونى با ضريب اثر V••ع/ بر روى توسعه صادرات كالاهاى ورزشى تأثير مى گذارد كه مناسب بودن برازش مدل ساختارى را تأييد مى كند. نتايج نشان داد شرايط و برخى شاخصهاى اقتصادى كشور بر توسعه صادرات كالاهاى ورزشى تاثير دارد. از اين رو شرايط و شاخصهاى اقتصادى به ميزان ب.V/· درصد از تغييرات توسعه صادرات

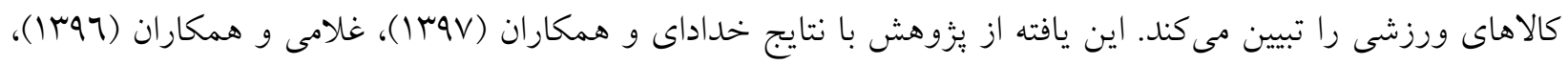




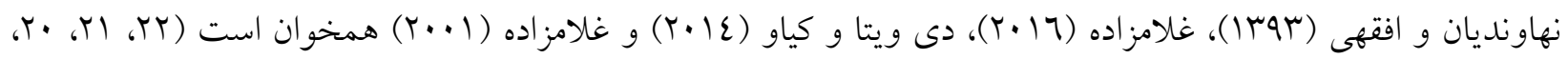
17 ، 9، ع). در تبيين اين يافته از يزوهش اين گونه مىتوان كفت كه شرايط اقتصادى نظير نوسانات غيرقابل بيشبينى نرخ ارز، ناطمينانى از نرخ ارز، تابعيت شاخص تورم، رشد سرمايه مو جود خالص كشور، وضعيت نرخ مخارج دولت، شاخص باز بودن اقتصاد به عنوان يك عامل درون گرا بر توسعه صادرات كالاهاى ورزشى تأثير مى گذارد. به طور مثال نرخ ارز حلقه قوى ارتباط اقتصادهاى ملى و جهانى است، حلقهاى كه كم و كيف آن به طور مستقيم و غير مستقيم در تعيين ميزان صادرات كالاهاى ورزشى و عرضه و تقاضاى اكثر كالاها و خدمات تأثير كذار و بر عملكرد اقتصاد ملى نيز مؤثر است. ديخر يافته يزوهش نشان داد كه سرمايه انسانى در بخش عوامل داخلى بر توسعه صادرات كالاهاى ورزشى تأثير دارد. از اين رو سرمايه انسانى به ميزان 79V/ • درصد از تغييرات توسعه صادرات كالاهاى ورزشى را تبيين مىكند. اين يافته از

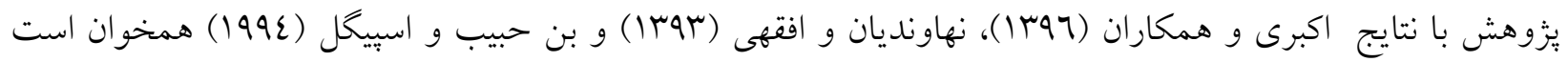

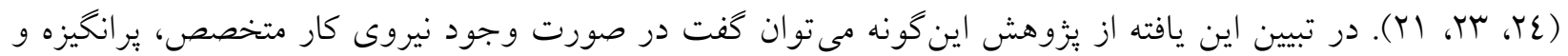
داراى نخرش مثبت نسبت توسعه صادرات و به طور كلى نسبت به رشد و توسعه كشور، همه اين عوامل موجب افزايش بهرهورى نيروى كار و به تبع آن افزايش توان رقابتى بنگاههاى ورزشى خواهد شد. بنابر اين در بخش عوامل داخلى توسعه صادرات، عوامل تخصصى نظير نيروى كار، پايهه مزيت رقابتى بايدار محسوب مىشوند كه يرورش اين عوامل خود امرى

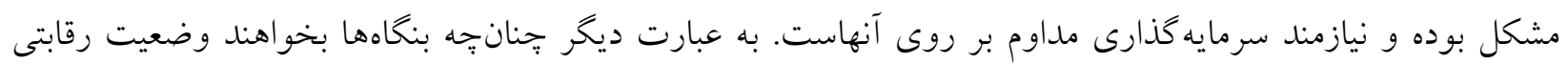
خود را ارتقاء دهند بايستى سرمايه كذارى مداوم به خلق نيروى كار متخصص و شايسته نمايند. ديخر يافته يزوهش نشان داد كه حمايتها و مشوقهاى نهادهاى دولتى در بخش عوامل داخلى بر توسعه صادرات كالاهاى ورزشى تاثير دارد. از اين رو حمايتها و مشوقهاى نهادهاى دولتى ع VI/ • درصد از تغييرات توسعه صادرات كالاهاى ورزشى را تبيين مى كند.

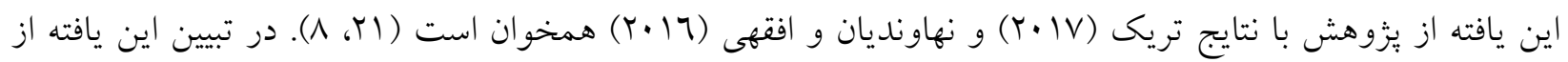
يزٔوهش اين گونه مىتوان كفت كشورهايى كه با برنامهاى حمايتى و تشويقى از توليد و صادرات كالاهاى ورزشى خود

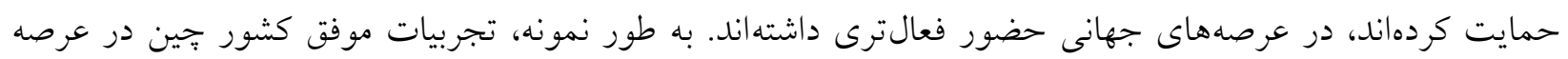
صادرات كالاهاى ورزشى، نشان مىدهد، دولت نقش مهمى در فرآيند توسعه صادرات اين كالاها بازى كرده است. جرا كه با انتخاب صنعت خاص ورزش و با حمايت هدفمند و مشروط، در يك دوره مشخص، سبب رشد صادرات كالاهاى اين صنعت برطرفدار شده است. اما مهمترين مشوقهاى صادراتى كه كشورهاى موفق در زمينه صادرات كالاهاى ورزشى به عمل آوردند، مواردى جون معافيت و تخفيفهاى مالياتى و طرحهاى استرداد حقوق گمركى، ايجاد صندوقهاى مالى لى و ارائه تسهيلات مالى با بهره كم، ارائه اطلاعات بازركانى، آموزش و مشاوره صادراتى، ايجاد دفاتر فعال در مراكز مهم صرم تجارى ورزشى دنيا، بازاريابى صادراتى و اعطاى وام براى توسعه بازار كالاهاى ورزشى، توسعه برند تجارى و اعتبار مالى هـ

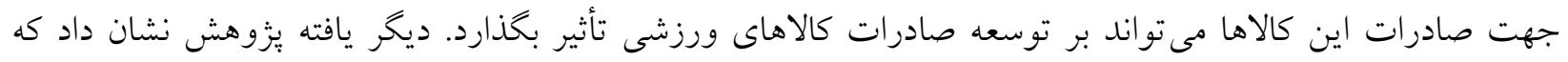

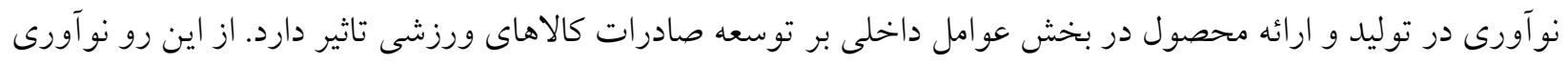
در توليد و ارائه محصول 170/ • درصد از تغييرات توسعه صادرات كالاهاى ورزشى را تبيين مى كند. اين يافته از يزوهش 


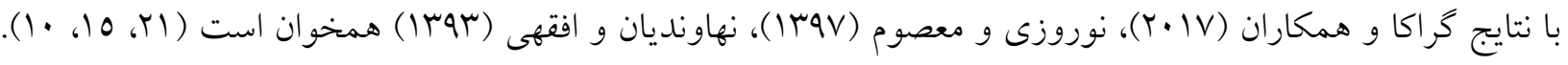
نتايج بيشتر اين يزوهشها نشان داد كه لازمه ورود به بازار جهانى صادرات كالاها، توسعه صنايع بيشرفته است و توسعه اين صنايع دانش محور، نيازمند توسعه فرهنگ نو آورى در توليد و ارائه محصول است. بنابراين براى دستيابى به قدرت

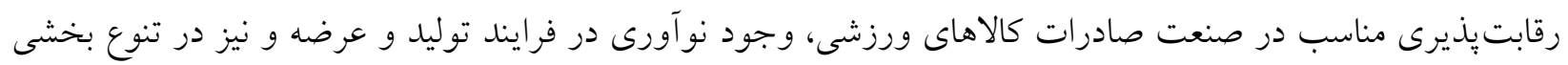
كالاهاى ورزشى، نحوه بستهبندى محصولات ورزشى، نوآورىهاى جديد در طراحى محصولات ورزشى، حضور در

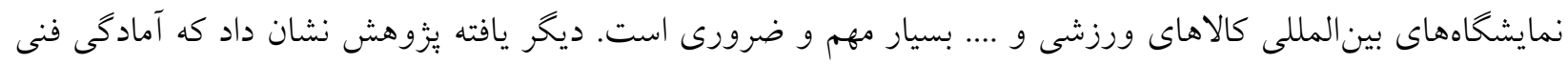
و تكنولوزيكى در بخش عو امل داخلى بر توسعه صادرات كالاهاى ورزشى تاثير دارد. از اين رو آمادكى فنى و تكنولوزيكى

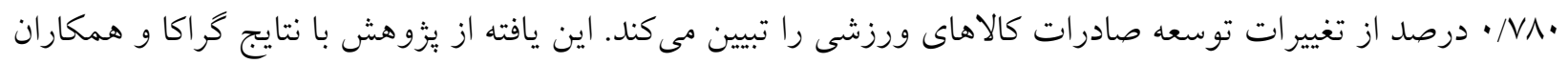
(Y. IV)، اوراو همكاران (YT) Y). در تبيين اين يافته از يزوهش اين گونه مىتوان كفت يكى از مهمترين عوامل در افزايش قدرت رقابتى و تسهيل در دستيابى به سهم بازارهاى بينالمللى در عرصه صادرات كالاهاى ورزشى، ورود جديدترين و علمىترين فناورى در توليد و عرضه كالاهاى ورزشى است. بديهى است كشورها تنها با اتكا به ابزارهاى سنتى و بدون بهرهكيرى از فناورىهاى جديد و رقابتى نمىتوانند در صحنه رقابت صادرات كالاهاى ورزشى توفيق لازم را به دست آورند. از اين رو امروزه به كارگيرى فناورى در توليد كالاها و محصولات ورزشى به امرى اجتناب نايذير تبديل شده است. بر اساس كزارشهاى اعلام شده، صادرات كالاهاى ورزشى ابتدايى از كمترين ميزان رشد نسبت به صادرات كالاهاى ورزشى با فناورى بالا در

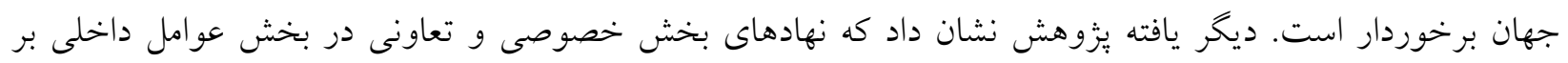

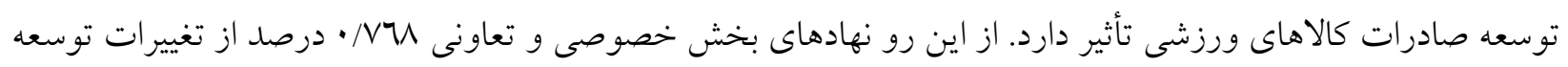
صادرات كالاهاى ورزشى را تبيين مى كند. اين يافته از يزوهش با نتايج تريك (Y. V. (Y) و زرندى و همكاران ( همخوان است (0r (1). نتايج بيشتر اين بزوهشها نشان از توجه ويزه به نقش تعاونىها و بخش خصوصى در فعاليت

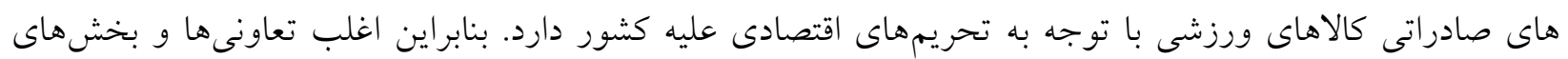
خصوصى مىتواند با شناسايى كامل بازارهاى هدف، جهت حضور در نمايشگاههاى بين المللى اقدام كنند و با استفاده از

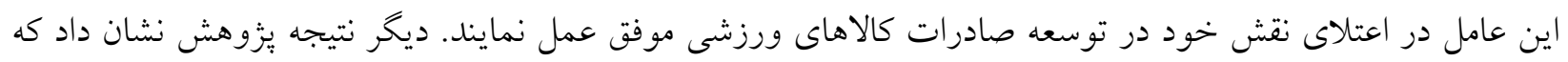
توانمندى بنخاهها در خصوص استراتزى و ساختار در بخش عوامل داخلى بر توسعه صادرات كالاهاى ورزشى تاثير دارد.

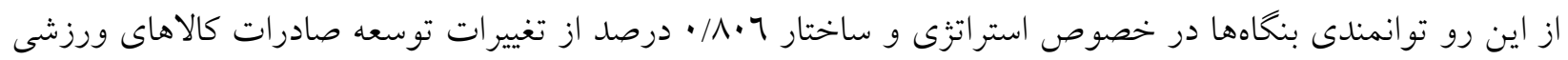

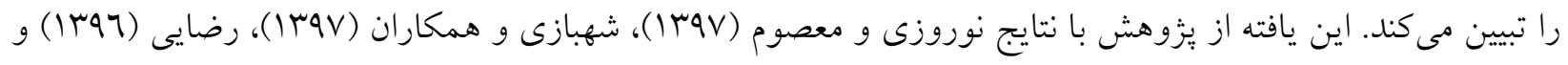

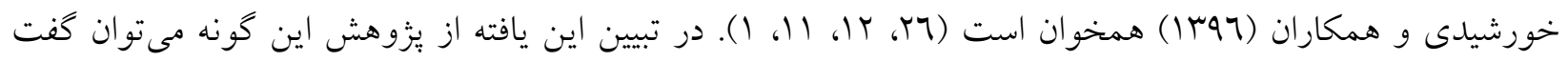
امروزه خلاء رويكرد استراتزيك در بازاريابى صادرات كالاهاى ورزشى به خوبى نمايان است. مشكلات اصلى در صادرات

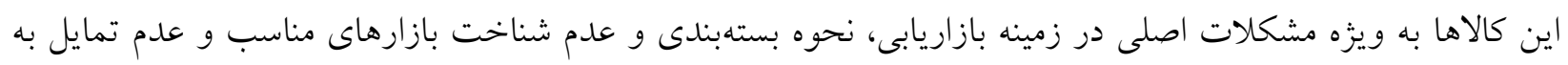
كسترش بازاريابى و تكامل دانششناختى، از مواردى هستند كه براى حل آنها نياز به استراتزى و ساختار مديريتى هدفمند 
احساس مىشود و تا تفكر و انديشه استراتزيك براى اصلاح اين مسائل وجود نداشته باشد، توسعه بازار صادراتى اين كالاها نيز امكانيذير نخواهد بود. تحقيقات در بازارهاى مقصد با توجه به سياستها و محدوديتهاى كشورهاى مقصد و مبدأ و تحقيق و بررسى بيرامون آنها از اقداماتى است كه بايد براى ورود به بازارهاى جهانى صادرات انجام شود و اين موضوع مستلزم برنامه استراتزيك بوده تا بر اساس آن برنامهاى جامع و علمى، طراحى و به اجرا كذاشته شود. بنابراين به

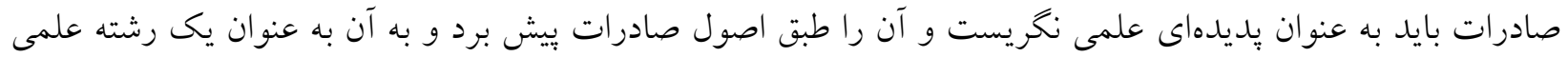

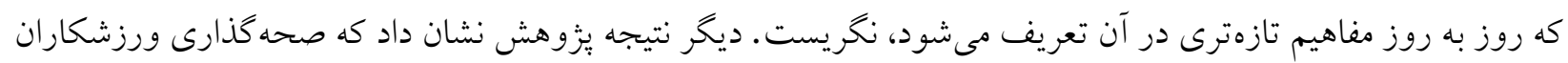
و متخصصين مشهور در بخش عوامل داخلى بر توسعه صادرات كالاهاى ورزشى تاثير دارد. از اين رو صحهذارى ورزشكاران و متخصصين مشهورر ا79/• درصد از تغييرات توسعه صادرات كالاهاى ورزشى را تبيين مىكند. اين يافته

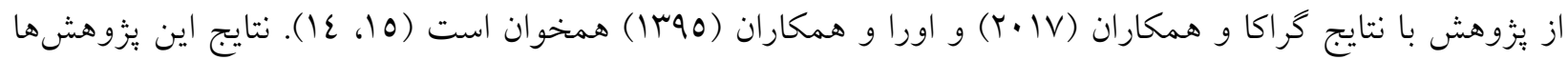
نشان داد كه شناخت عواملى كه بتو انند با صحه كذارى و تأييد كردن محصولات از طريق ورزشكاران بر مشتريان تأثير بحذارند، براى ورزشكاران و مديران سازمانهاى صنعتى ضرورى مىباشد تا آنها بتواند از اين طريق و به منظور جذب مشترى بيشتر جهت فروش محصولات خود، سرمايه كذارى كرده و تمركز مناسبى بر اين عوامل داشته باشند. در تبيين اين يافته اين گونه مى توان كفت كه با درك بهتر رفتار خريد مشتريان و شناخت نحوه خريد مشتريان فعلى و كروه بالقوه

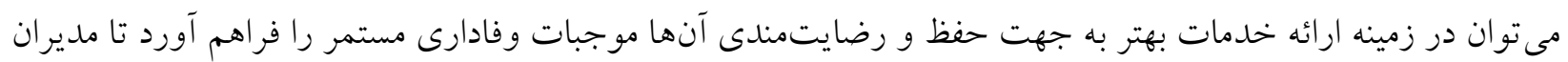
از مزاياى بىشمار حاصل از حضور و خريد مشتريان بهرهمند گردد. ديخر نتيجه يزوهش نشان داد كه بيوندهاى تجارت و توانمندى در اقتصاد بين المللى در بخش عوامل خارجى بر توسعه

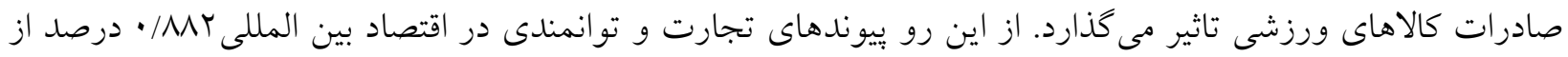

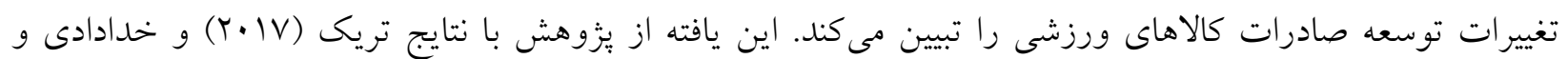
همكاران (Vوr|) همخوان است (II)، 1). از اين رو و با توجه به يافتهاى اين يزوهش انجام توافقنامهاى تجارى مشترى با برندهاى معتبر ورزشى جهانى، عضويت كشورمان در سازمان جهانى تجارت، ارتباط مؤثر و مستمر بنگاههاى ورزشى كشور با مراكز يزوهشى و تحقيقاتى جهانى، اتحادهاى راهبردى با شركتهاى بين المللى بزرى ارائه دهنده

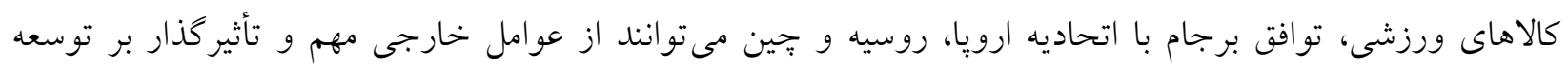
صادرات كالاهاى ورزشى باشند. يافته ديخر يزوهش نشان داد كه سياست تجارت خارجى در بخش عو بامل خل خارجى بر توسعه صادرات كالاهاى ورزشى تاثير مى گذارد. از اين رو سياست تجارت خارجى ه0^/ • درصد از تغييرات توسعه صادرات كالاهاى ورزشى را تبيين مى كند. اين يافته از يزوهش با نتايج گراكاو همكاران (Y.|V) و خدادادى و همكاران

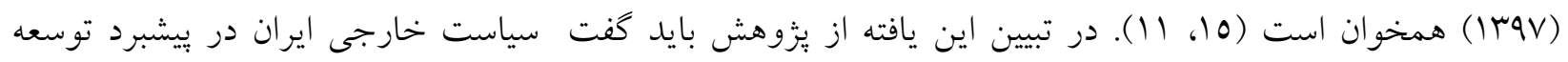
صادرات كالاهاى ورزشى و افزايش رشد اقتصادى كشور نقش كليدى دارد و بدون توجه به سياستهاى تجارى تأثير كذار خارجى، توسعه صادرات كالاهاى ورزشى در ايران اتفاق نمى افتد. از اين رو اتخاذ سياست خارجى توسعهكرا در جهت رشد و بهبود وضعيت صادرات كالاهاى ورزشى كشور بسيار مهم و حائز اهميت است. 
بدون شك امروزه از اصلىترين راههاى فعالتر كردن اقتصاد هر كشور توجه جدى به صادرات، ييدا كردن بازارهاى جديد صادراتى و رفع موانع ييش روى صادرات است. به طورى كه رشد و توسعه صنعت صادرات كالاهاى ورزشى كشور، نتيجه شناسايى دقيق عوامل داخلى، عوامل خارجى و به طور كلى بازار صادراتى است. بنابراين در بخش عوامل داخلى فراهمسازى فضاى امن و يرسود براى سرمايه كذارى در بخشهاى توليدى و مولد مناسب با توجه به شرايط بيّجيده و سخت و جالشها و مشكلات موجود، اختصاص تسهيلات، يارانه، ارز دولتى و وام براى واردات مواد اوليه مورد نياز توليدكندكان داخلى، وجود استراتزى و ساختار براى شركتها و توليدىها و بازاريابى آنها، تقويت و مديريت حرفهاى منابع انسانى، اختصاص بستهاى حمايتى و تشويفى و ...... مىتواند بر توسعه صادرات كالاهاى ورزشى اثر كذار باشد. از طرفى روابط و سياست تجارت خارجى يكى از عوامل موثر بر توسعه صادرات كالاهاى ورزشى و رشد اقتصادى كشور در بلندمدت است. روابط خارجى كار آمد و سازنده با كشورهاى جهان، يكى از مؤلفههاى اصلى توسعه صادرات كالاهاى

ورزشى، كاهش ريسك و ناطمينانى براى سرمايه گذارى در اين زمينه است. از اين رو سياست تجارت خارجى مىتواند مشوق جذب سرمايه كذارى خارجى باشد، مىتواند به تأمين كمك خارجى براى توسعه كشور كمك كند و در نهايت همكارى مشترى اقتصادى و توليد و در نتيجه توسعه و رشد اقتصادى كشور را تسريع كند.

1. Shahbazi, H. Shakibania, B. Abbasifar, A. (2018). Evaluate the functions of the government incentive program on export performance. Journal of Business Management Exploration. 10 (19): 20-1.

2. Shoghi, B. Hazuri, M. Delavari, A. (2015). Identify and rank the factors affecting the development of entrepreneurs' exports in international markets. Journal of Modern Marketing. 16(17): 122-11.

3. Esfidani, M. Hassan Gholipour Yasuri, T. Turkestani, M. Rouhani, A. (2018). Typology of export behavior of exporting companies in Iran's electricity industry. Journal of Business Management. 10(1): 30-1.

4. Malik, T. Varieties of capitalism, innovation performance and the transformation of science into exported products: A panel analysis. Journal Technological Forecasting \& Social Change. 2017; 118(1): 324-333.

5. Gholamzadeh Fasandoz, H. (2016). Sport as an Industry in Finland- Exploring the Economic Significance, Contributions, and Development of the Sport Sector as an Industry. Academic dissertation to be publicly discussed, by permission of the Faculty of Sport and Health Sciences of the University of Jyvaskyla.

6. Gholamzadeh Fasandoz, H. (2016). Sport as an Industry in Finland- Exploring the Economic Significance, Contributions, and Development of the Sport Sector as an Industry. Academic dissertation to be publicly discussed, by permission of the Faculty of Sport and Health Sciences of the University of Jyvaskyla.

7. Weiss, Atmar. (2011), "Principles of sociology of sport, Kramtallh translation firm", Reed Publishing Press, 336 pp, Tehran. 
8. Tariq H. Malik. (2017). Varieties of capitalism, innovation performance and the transformation of science into exported products: A panel analysis. Journal Technological Forecasting \& Social Change. 118(1): 324-333.

9. Khodadadi, M., Sarlab, M., \& Masoum Zadeh, S. Impact of exchange regimes on the flow of business goods in the Middle East countries: Space econometric approach. Sports Management Studies. 2018; 10(48): 36-17. (In Persian)

10. Nourozi, N., \& Masoum, M. Designing the Model of Factors Affecting Export Performance of Sporting Equipment Manufacturers. Sports Management Studies. 2018; 10(49): 18-11. (In Persian)

11. Rezaei, R. (2017). Influence of export performance on international marketing strategies. Journal of Business Management Exploration. 17(1): 80-55.

12. Mofradi, S. Sheikhzadeh, M. (2015). Influence of perceiving regional export development barriers on the characteristics of exporters. Journal of Business Management Exploration. 15(1): 184-165.

13. Graça Miranda. S. Paulo J. Gomesb.I. \& Luis Filipe. L. (2017). Does importer involvement contribute to product innovation? The role of export market factors and intra-firm coordination. Journal Industrial Marketing Management. 14(1): 14-1.

14. Oura. MM. Zilber. SN. Lopes. EL. (2016). Innovation capacity, international experience and export performance of SMEs in Brazil. International Business Review. 25(4):921-32.

15. Jorg Henseler, Christian M. Ringle andRudolf R. Sinkovics. (2009). The use of partial least squares path modeling ininternational marketing. The University of Manchester Research. Volume 20, 277-319.

16. Andreff, M., Andreff, W. (2009). Global Trade in Sports Goods: International Specialisation of Major Trading Countries. European Sport Management Quarterly, 9:3, 259-294.

17. Gholamzadeh, H. (2001). Export and Import of sporting goods. M.Sa Thesis in sports planning and administration, Faculty of sport \& health sciences, University of Jyvaskyla.

18. Gholami, A., Zare, A., Ghalavand, A., \& Shirali, R. Investigating the Factors Affecting the Formation of Small and Medium Enterprises in the Sports Industry of the Country. Journal of Applied Research in Sport Management. 2017; 6(22): 66-57. (In Persian(

19. Nahavandian, M., \& Afghahi, B. Factors Influencing the Export of High-Tech Services in the Islamic Republic of Iran. Economic Research Journal. 2014; 14(4): 56-23. (In Persian)

20. DeVita. G. (2014). The long run impact of exchange rate regimes on international tourism flows. Journal of Tourism Management. 45(2): 226-33.

21. Akbari, A., Poor Ebadolahan, M., Mohammad Zadeh, P., \& Rezaei, S. Space Analysis Factors Affecting the Exports of Food and Drinking Industries. Quarterly of Applied Economics Theories. 2017; 4(1): 197-218. (In Persian)

22. Benhabib. J. \& Spiegel. M. (1994). The role of human capital in economic development evidence from aggregate cross-country data. Journal of Monetary Economics. 34(2): 143-73 .

23. Yousefi Zarandi, M., Sharifian, E., \& Ghahreman Tabrizi, K. Barriers to the competitiveness of domestic goods with foreign samples in the manufacturing sector of the sports industry in Iran. Journal of Contemporary Research in Sport Management. 2016; 6(11): 83-73. (In

Persian) 
24. Khorshidi, G., Hajipour, B., Azizi, S., \& Hanzel Eidani, H. Designing and explaining the pattern of export development in Iran's free trade zones. Quarterly Journal of Business Research. 2017; 21(83): 65-35. (In Persian) 